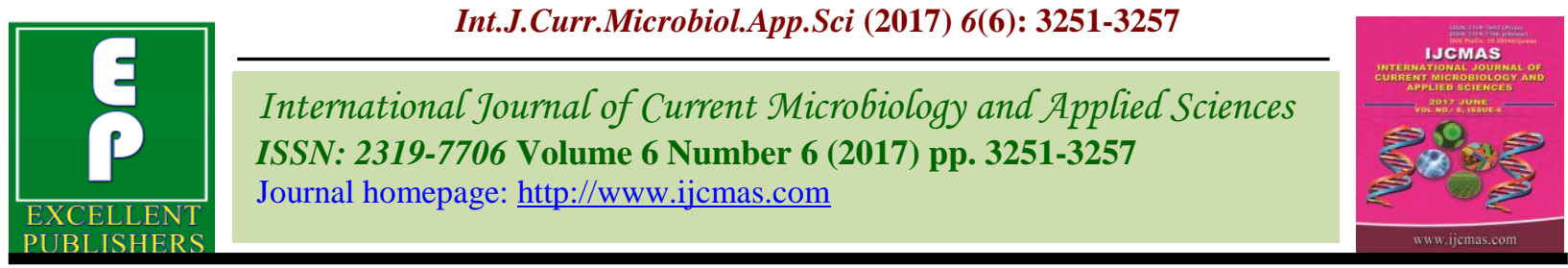

Original Research Article

https://doi.org/10.20546/ijcmas.2017.606.383

\title{
Media Habits among Tribal Women Organic Farmers in Kandhamal District of Odisha, India
}

\author{
D.V. Singh ${ }^{1^{*}}$, U.S. Gautam ${ }^{2}$ and D. S. Chhonkar ${ }^{3}$ \\ ${ }^{1}$ KVK, Kandhamal, OUAT, Bhubaneswar, India \\ ${ }^{2}$ ICAR-ATARI, Zone-IV, Kanpur, India \\ ${ }^{3}$ KVK, Tawang (Arunachal Pradesh), India \\ *Corresponding author
}

\begin{tabular}{|c|c|}
\hline & A B S T R A C T \\
\hline $\begin{array}{l}\text { Agricultural } \\
\text { information, } \\
\text { Dissemination, } \\
\text { Mass media, } \\
\text { Media habits, } \\
\text { Organic farmers, } \\
\text { Tribal Women. }\end{array}$ & \multirow{3}{*}{$\begin{array}{l}\text { Mass Media are used as channels of mass communication. The main purpose of } \\
\text { media is to inform, educate and motivate the community to accept new ideas and } \\
\text { technologies so as to enhance their living conditions. The mass media plays a very } \\
\text { significant role in agricultural development and dissemination of latest agricultural } \\
\text { technologies among the farmers. This paper tries to examine the media habits } \\
\text { among women organic farmers, to know the time given to each media by women } \\
\text { and to find out the popular media among women. For the present research multi } \\
\text { stage sampling design was used. The sample consists of } 122 \text { women farmers and } \\
\text { the Pre-tested questionnaire was used for collection of information. The data } \\
\text { reveals that majority of the respondents spend one hour for every media and the } \\
\text { interesting finding of the study indicates that } 62.29 \% \text { of the respondents do not } \\
\text { accessed internet at all. Only } 0.81 \% \text { of the respondents do not view TV, so the } \\
\text { findings show that TV is the most popular media among women organic farmers. }\end{array}$} \\
\hline Article Info & \\
\hline $\begin{array}{l}\text { Accepted: } \\
\text { 15 May } 2017 \\
\text { Available Online: } \\
10 \text { June } 2017\end{array}$ & \\
\hline
\end{tabular}

\section{Introduction}

Agriculture in India has a significant history. Today, India ranks second worldwide in farm output. Agriculture and allied sectors like forestry and fisheries accounted for $16.6 \%$ of the GDP in 2009, about $50 \%$ of the total workforce. The economic contribution of agriculture to India's GDP is steadily declining with the country's broad-based economic growth. Still, agriculture is demographically the broadest economic sector and plays a significant role in the overall socio-economic fabric of India and the women play a crucial role in all farm-related activities from land preparation to marketing.
They contribute a higher proportion of labor work in agricultural sector than men. However, they are not active in decision making (Tara Satyavathi et al., 2013). The mass media are diversified media technologies that are intended to reach a large audience by mass communication. Mass media are very essential tools for the transfer of information about agriculture sector and mass media plays a very significant role in agricultural development and dissemination of latest agricultural technologies among the farmers. The technology through which this communication takes place varies. Broadcast 
media such as radio, recorded music, film and television transmit their information electronically. Print media use a physical object such as: newspaper, book, magazines, pamphlet etc. to distribute their information. Mass media have more influenced on women. Television and mobile phones have more effective media in today's society. The media through which the data transfer takes place has also undergone revolutionary change.

Telephone lines are still the popular source in India although the reliability and low bandwidth are still major issues. High capacity cables, optical fiber, radio, wireless local loops, satellite transmission and various solutions based on a combination of these are already being used in many parts of the country. Technologically it is possible to develop suitable systems, to cater to the information needs of Indian farmer. User friendly systems, particularly with content in local languages, can generate interest in the farmers and others working at the grassroots. It is possible to create dedicated networks or harness the power of internet to make these services available to all parts of the country. The rapid changes in the field of information technology make it possible to develop and disseminate required electronic services to rural India.

\section{Materials and Methods}

Research design is the plan and structure to obtain the solution to the research problem. The study was conducted in Kandhamal district of Odisha state during the year 2016. For the present research multi stage sampling design was used for selection of the respondents. This would represent a two stage sampling design with the ultimate sampling units being clusters of districts (Kothari C.R1991). Sample consisted of 122 women farmers and the Pre-tested questionnaire was used for collection of information.

\section{Results and Discussion}

\section{Statement of the Problem}

Mass media plays a vital role in developing country like India. Women play a crucial role in all farm-related activities from land preparation to marketing. They contribute a higher proportion of labor work in agricultural sector than men. Hence it is necessary to study on the "Media habits among tribal women organic farmers in Kandhamal district of Odisha" to assess the media habit among women farmers, to know the time given to each media by women and to find out the popular media among women farmers.

\section{Findings and discussions}

Age

Table 1 reveals that majority of the respondents i.e., $39.34 \%$ belonged to below 25 years age group followed by $26-35$ years age group $(23.77 \%)$ whereas, the same percentage i.e. $(23.77 \%)$ belonged to $36-45$ years age group and only $13.11 \%$ of the respondents belonged to old age group (46 years and above).

\section{Education}

It was noticed from the above table that most of the respondents $(45.90 \%)$ were completed their education up to college level followed by $31.96 \%$ were primary and secondary education while, $12.29 \%$ were completed post-graduation and it is interesting to note that only $9.0 \%$ were illiterate and remaining $0.8 \%$ were from other education category. Similar results also found by Hasan Shamsul and Sharma Arpita (2011) that maximum number of respondents $(60 \%)$ had completed education up to graduate level. 


\section{Size of land holding}

Data reported from the table 1 that more than half $(59.83 \%)$ of the respondents had very less marginal farm size (up to 5 acres) followed by $25.40 \%$ had small farm size (610 acres).Whereas, $10.65 \%$ of the respondents were medium farmers (11-20 acres) and very less (4.09\%) had big farm size (21 acres and above).

\section{Annual income}

Further, with respect to categorization of respondents based on annual income, the results presented in table 1 stated that majority of the respondents $45.08 \%$ belonged to low income level (Up to 20 thousand) followed by $22.95 \%$ of the respondents belonged to $21-50$ thousand income level. While, $18.03 \%$ were 51 thousand-1 lakh income level and only $13.93 \%$ were in the high income group (1 lakh and above). The results of the study get the support from the Malagar Geeta (2007) that Majority of the respondents had low level (i.e. less than Rs.12, 000) of annual income.

Table.1 Socio personal profile of the respondents

\begin{tabular}{|c|c|c|}
\hline Characteristics & No. of respondents & Percentage \\
\hline \multicolumn{3}{|l|}{ Age } \\
\hline Below 25 years & 48 & 39.34 \\
\hline $26-35$ years & 29 & 23.77 \\
\hline $36-45$ years & 29 & 23.77 \\
\hline 46 years and above & 16 & 13.11 \\
\hline \multicolumn{3}{|l|}{ Education } \\
\hline Illiterate & 11 & 09.00 \\
\hline Primary and Secondary & 39 & 31.96 \\
\hline College & 56 & 45.90 \\
\hline Post-graduation & 15 & 12.29 \\
\hline Any other & 01 & 00.80 \\
\hline \multicolumn{3}{|l|}{ Size of land holding } \\
\hline Up to 5 acres & 73 & 59.83 \\
\hline 6-10 acres & 31 & 25.40 \\
\hline $11-20$ acres & 13 & 10.65 \\
\hline 21 acres and above & 05 & 04.09 \\
\hline \multicolumn{3}{|l|}{ Annual income } \\
\hline Up to 20 thousand & 55 & 45.08 \\
\hline $21-50$ thousand & 28 & 22.95 \\
\hline 51 thousand to one lakh & 22 & 18.03 \\
\hline 1 lakh and above & 17 & 13.93 \\
\hline \multicolumn{3}{|l|}{ Media ownership } \\
\hline Newspaper & 82 & 67.21 \\
\hline TV & 112 & 91.80 \\
\hline Radio & 87 & 71.31 \\
\hline Internet & 34 & 27.86 \\
\hline Mobile & 117 & 95.90 \\
\hline
\end{tabular}


Table.2 Number of hours spent by respondents in reading newspaper

\begin{tabular}{|c|c|c|}
\hline Duration & No. of respondents & Percentage \\
\hline 1 hour & 78 & 63.93 \\
\hline 2 hours & 12 & 09.83 \\
\hline 3 hours & 07 & 05.73 \\
\hline More than 3 hours & 03 & 02.45 \\
\hline Never & 22 & 18.03 \\
\hline Total & 122 & 100.00 \\
\hline
\end{tabular}

Table.3 Number of hours spent by respondents in reading magazines

\begin{tabular}{|c|c|c|}
\hline Duration & No. of respondents & Percentage \\
\hline 1 hour & 72 & 59.01 \\
\hline 2 hours & 17 & 13.93 \\
\hline 3 hours & 03 & 02.45 \\
\hline More than 3 hours & 01 & 00.81 \\
\hline Never & 29 & 23.77 \\
\hline Total & 122 & 100.00 \\
\hline
\end{tabular}

Table.4 Number of hours spent by respondents in reading farm magazine

\begin{tabular}{|c|c|c|}
\hline Duration & No. of respondents & Percentage \\
\hline 1 hour & 83 & 68.03 \\
\hline 2 hours & 13 & 10.65 \\
\hline 3 hours & 01 & 00.81 \\
\hline More than 3 hours & 01 & 00.81 \\
\hline Never & 24 & 19.67 \\
\hline Total & 122 & 100.00 \\
\hline
\end{tabular}

Table.5 Number of hours spent by respondents in listening radio

\begin{tabular}{|c|c|c|}
\hline Duration & No. of respondents & Percentage \\
\hline 1 hour & 42 & 34.42 \\
\hline 2 hours & 26 & 21.31 \\
\hline 3 hours & 04 & 03.27 \\
\hline More than 3 hours & 13 & 10.65 \\
\hline Never & 37 & 30.32 \\
\hline Total & 122 & 100.00 \\
\hline
\end{tabular}


Table.6 Number of hours spent by respondents in watching tv

\begin{tabular}{|c|c|c|}
\hline Duration & No. of respondents & Percentage \\
\hline 1 hour & 35 & 28.68 \\
\hline 2 hours & 22 & 18.03 \\
\hline 3 hours & 14 & 11.47 \\
\hline More than 3 hours & 50 & 40.98 \\
\hline Never & 01 & 00.81 \\
\hline Total & 122 & 100.00 \\
\hline
\end{tabular}

Table.7 Number of hours spent by respondents in accessing internet

\begin{tabular}{|c|c|c|}
\hline Duration & No. of respondents & Percentage \\
\hline 1 hour & 40 & 32.78 \\
\hline 2 hours & 05 & 04.09 \\
\hline 3 hours & 01 & 00.81 \\
\hline More than 3 hours & 00 & 00.00 \\
\hline Never & 76 & 62.29 \\
\hline Total & 122 & 100.00 \\
\hline
\end{tabular}

Table.8 Number of hours spent by respondents in using mobile

\begin{tabular}{|c|c|c|}
\hline Duration & No. of respondents & Percentage \\
\hline 1 hour & 61 & 50.00 \\
\hline 2 hours & 15 & 12.29 \\
\hline 3 hours & 10 & 08.19 \\
\hline More than 3 hours & 31 & 25.40 \\
\hline Never & 05 & 04.09 \\
\hline Total & 122 & 100.00 \\
\hline
\end{tabular}

\section{Media ownership}

The data presented in above table shows that majority of the respondents owned TV $(91.80$ $\%)$ and mobile phone $(95.90 \%)$ followed by radio $71.31 \%$ and newspaper $67.21 \%$. while, only $27.86 \%$ of the respondents had internet facility in their house. The findings of the present study are in conformity with the closely related study of Hasan Shamsul and Sharma Arpita (2011) reported that all the respondents owned television and mobile phone. The data recorded in table 2 indicated that majority of the women $(63.93 \%)$ spend 1 hour daily for reading newspaper followed by
2 hours $9.83 \%$. whereas, $5.73 \%$ women spend 3 hours for reading newspaper and only $2.45 \%$ spend more than 3 hours. Further, $18.03 \%$ of the respondents were do not read newspaper at all.

It was found from the table 3 that majority of the respondents $(59.01 \%)$ used to spend 1 hour in reading general magazines followed by $13.93 \%$ spend 2 hours. While, $2.45 \%$ spend 2 hours and a very small number of women $(0.81 \%)$ spend more than three hours in reading general magazines. Therefore, $23.77 \%$ of the women do not read magazines. Table 4 reported that nearly one third of the 
respondents $(68.03 \%)$ spend an hour in reading farm magazine while $10.65 \%$ of respondents spend 2 hours and similarly 0.81 $\%$ of the respondents spend 3 hours and more than 3 hours in reading farm magazine. Though, $19.67 \%$ of women do not read farm magazine at all. This finding is in accordance with the findings of Hanumanaikar Raveendra (2009) depicts that $51.67 \%$ of the respondents were spent 30-60 minutes in reading of farm magazine every week.

It was observed from the table 5 that maximum number of respondents $(34.42 \%)$ spend 1 hour in listening radio, followed by 2 hours $21.31 \%$, while $10.65 \%$ were spend more than 3 hours for radio listening and only $3.27 \%$ of the respondents spend 3 hours. Further it was found that $30.32 \%$ women do not listen to radio at all. This is supported by the findings of Sathawane et al. (1989) found that $34.13 \%$ did not listen farm radio programmes at all.

Table 6 shows that most of the respondents (40.98\%) spend more than three hours in watching television followed by $28.68 \%$ were spend 1 hour, whereas, $18.03 \%$ spend 2 hours and only $11.47 \%$ of the women spend 2 hours daily in watching television. It was interesting note that very few $(0.81 \%)$ of the women do not watch television. These results were in accordance with the findings of Laldinliana (2012) observed that $37.03 \%$ spend three hours and more a day in watching TV on weekends while one-third of the respondents devote around two hours on such days.

It was noticed from the table 7 that majority of the respondents $(32.78 \%)$ spend 1 hour in accessing internet daily followed by $4.09 \%$ spend 2hours, while $0.18 \%$ spend three hours a day and $0 \%$ of the women never spend more than three hours for internet access. The interesting finding was that more than half of the respondents (62.29 \%) do not access internet at all. The reason behind that due to lack of internet facility they do not use internet.

Analysis of the acquired data in the table 8 shows that maximum number of respondents i.e. $50 \%$ use mobile phones daily 1 hour followed by $25.40 \%$ use it for more than 3 hours, $12.29 \%$ use 2 hours daily and only $8.19 \%$ of the women use mobile for 3 hours. While, only $4.09 \%$ of the respondents do not use mobile phone. The results of the above table indicated that due to the fast growth of satellite communication (mobile technology) a majority of respondents have use mobile.

In conclusion, the main purpose of media is to inform, educate and motivate the community to accept new ideas and technologies so as to enhance their living conditions. The reading habit of rural educated women is more due to high literacy level. Only a small number of women do not read newspaper, magazine and farm magazine respectively. They read newspaper and magazines for information and entertainment purpose. Nearly one third of the women listen to the radio and $99.18 \%$ of the respondents watch television daily among them majority of women spend more than three hours a day. Television and mobile were emerged as most utilized media among women as compare to other media. The study also indicates that more than half of the respondents do not use internet due to lack of internet facility and technology illiteracy. It can be concluded that television and mobile phones are the most popular media among women for edutainment and communication.

\section{References}

Becker A.E. (2004) „Television, Disordered Eating, And Young Women In Fiji: Negotiating Body Image And Identity During Rapid Social Change ${ }^{e e}$, Culture, 
Medicine and Psychiatry 28: 533-559, 2004. Department of Psychiatry, Massachusetts General Hospital Boston, MA, USA.

Hanumanaikar Raveendra H. (2009) „A Study On Reading Habits, Preference Pattern And Satisfaction Level Of Kannada Farm Magazines Readerse', Department Of Agricultural Extension Education College Of Agriculture, Dharwad University Of Agricultural Sciences, Dharwad - 580005.

Hasan Shamsul and Sharma Arpita (2011) „Print Media Utilization Pattern among Homemakerse, Global Media Journal Indian Edition/ Summer Issue / June 2011, pp- 1- 17.

Laldinliana, 2012. Electronic Media Habits in Tribal Economy: an Empirical Study on Rural and Urban Mizoram"e, EXCEL International Journal of Multidisciplinary Management Studies Vol.2 Issue 4, April 2012, ISSN 2249 8834 Online available at http://zenithresearch.org.in/.

Malagar Geeta (2007). Radio Listening and Televiewing Behaviour of Rural Women"e, Department of Extension and Communication Management College of Rural Home Science, Dharwad University of Agricultural Sciences, Dharwad - 580005 .
Oakbrook Terrace, IL, May 27, 2009 ---The JSH\&A 2009 Women"s LIFTM Media Habits Survey. http://www.jsha.com/ wp-content/ uploads/study-on-womenmedia-release.pdf.

Oby Maureen Nwafor and Felicia N. Akubue (2008) „Nigerian urban women information media: The challenges for women in leadership"e, Educational Research and Review Vol. 3 (9), pp. 309-315, October, 2008. http://www.academicjournals.org/ERR.I SSN 1990-3839 (C) 2008 Academic Journals.

Sathawane, R.A., Agarwal, S. K, and Sonoria, Y.C. (1989) „Radio listening behavior of farmers". Maharashtra J. Extn. Edu. 8: 273-275.

Tara Satyavathi C., Bharadwaj Ch. and Brahmanand P.S. „Role of Farm Women in Agriculture Lessons Learned, http://gtd.sagepub.com/ content/14/3/441.abstract.

The role of women in agriculturee Prepared by the SOFA Team and Cheryl Doss. http://www.fao.org/docrep/013/am307e/ am307e00.pdf.

Winkipedia. Role of Information Technology in Agriculture and its Scope in India S.C. Mittal, 1.

\section{How to cite this article:}

Singh, D.V., U.S. Gautam, and Chhonkar, D. S. 2017. Media Habits among Tribal Women Organic Farmers in Kandhamal District of Odisha. Int.J.Curr.Microbiol.App.Sci. 6(6): 32513257. doi: https://doi.org/10.20546/ijcmas.2017.606.383 